\title{
الإسلام السياسي في النقد العربي: مراجعة في الخطاب
}

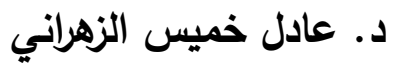

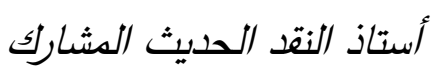

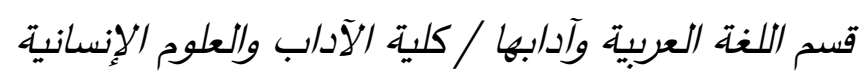 \\ جامعة الملك عبدالعزيز
}

ملنص. منذ ظهور الأحزاب والجماعات الإسلامية في ستينات القرن الميلادي المنصرم حاول المفكرون والنقاد

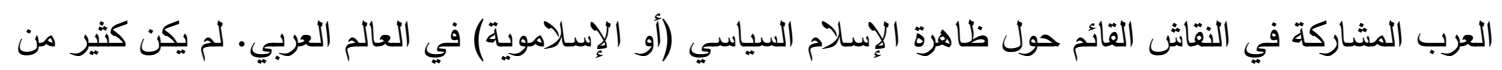

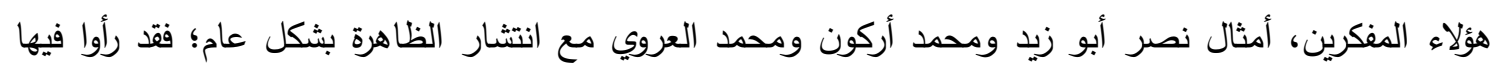

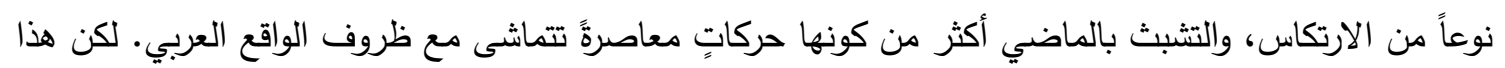

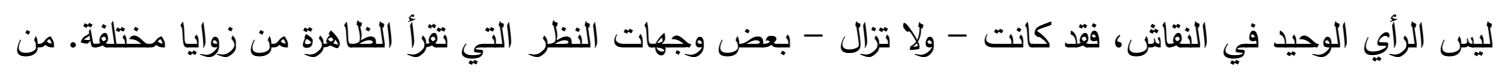

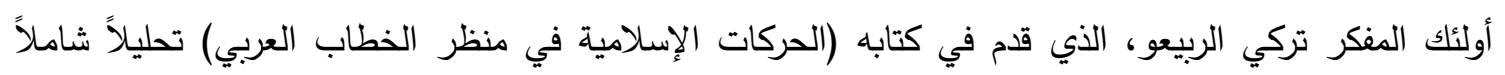

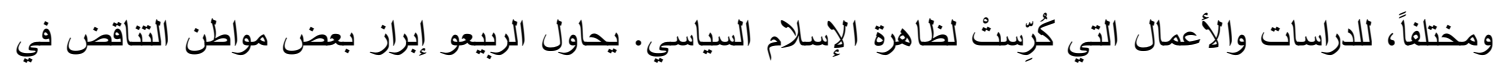

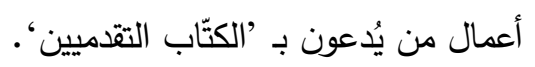

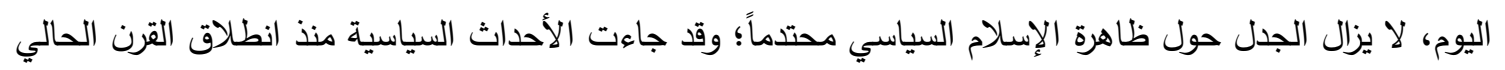

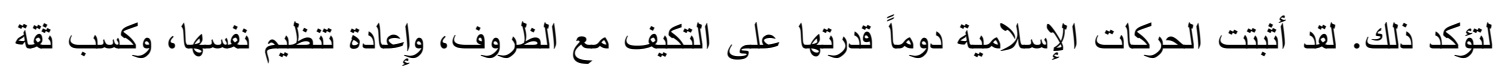

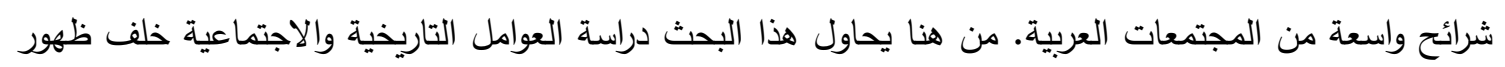

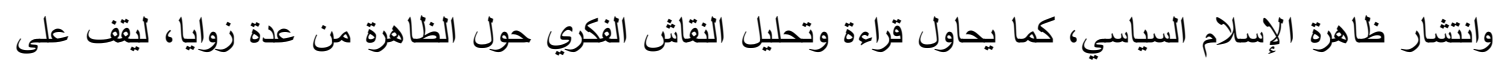
مواطن القصور في فهم الخطاب النقدي العربي لديناميكية الحركات الإسلامية الدعاصرة.

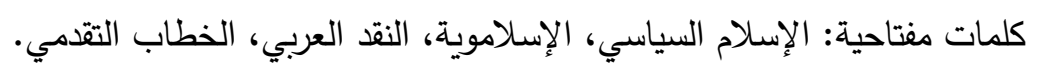


historical context, but also by examining the socio-cultural factors behind the people's devotion to Islam, and thus potentially to those who claim, however falsely, to be its true political representatives.

Steppat also draws attention to this issue in his book on fundamentalism; he notes "that present trends in Jordan and Algeria suggest that Islam may gain power as a result of democratic majorities" and therefore, he urges the world to "stop regarding it as an enemy. Islam feels threatened by the West and is on the defensive. By viewing it as an enemy we fail to understand it and postpone its appeasement" (Warburg, 2009: 662). We seem to be witnessing the fulfilment of Steppat's prophecy, and the coming years should tell whether or not the world will heed his warning to understand Islam.

\section{References $^{\bullet}$}

- Abu Zayd, Naṣr. Naqd al-Khiṭāb al-Dīni. $2^{\text {nd }}$ ed. Cairo: Sīna li al-Nashr, 1994.

- Aksikas, Jaafar. Modernities: Islamism, Nationalism, and Liberalism in the Postcolonial World. New York: Peter Lang, 2009.

- Al-Rabī̄ū, Turki. Al-Harkāt al-'Islāmiyya fi Manzūr al-Khitāb al-'Arabi. Casablanca: alMarkaz al-Thaqāfi al- 'Arabi, 2006.

- Al-'Awdāt, Husayn. al-Nahḍa wa al-Hadātha Bayn al-'Irtibāk wa al-'Ikhfāq. Beirut: Dār al-Sāqi, 2011.

- Arkoun, Mohammad. Tārīkhiyyat al-Fikr al'Arabi. $2^{\text {nd }}$ ed. Casablanca: al-Markaz alThaqāfi al-'Arabi, 1996.

- Baqader, Abubaker. "Contemporary Islamic Movements in the Arab World", Islam, Globalization, and Postmodernity. eds. Akbar Ahmed \& Hastings Donnan. London: Routledge, 1994.

- Lewis, Bernard. The Future of the Middle East. London: Orion, 1997.
- Ménoret, Pascal. The Saudi Enigma: A Histroy. London: Zed Books, 2005.

- Ruthven, Malise. "The Islamist Movement in the Middle East and North Africa", The Middle East and North Africa. $53^{\text {rd }}$ ed. London: Routledge, 2007.

- Stern, Jessica \& Berger, J.M. ISIS the State of Terror. London: William Collins, 2015.

- Warburg, Gabriel R. "From Sufism to Fundamentalism: The Mahdiyya and the Wahhabiyya", Middle Eastern Studies. 45.(4) (2009).

\footnotetext{
- Arabic books are transliterated.
} 
of feudalism, as it was in Europe', and therefore 'it must be fought and defeated' as Fayșal Darrāj insists. Abdulla Hinna, by contrast, considers Islam the revolutionary ally of the revolutionary Arab regimes and the spokesman of the bourgeoisie because it rejects feudalism. It is, in Mahmūd Amīn al'Ālim's opinion the initial ally of capitalism, while Rif at al-Sayyid believes that Political Islam is 'a capitalist ideology wearing a white robe and a beard' and, surprisingly, it could be the 'proponent of colonial attacks' according to al-'Azm.

This conspiratorial mentality is, Al-Rabî̀ $\bar{u}$ concludes, the result of a lack of objectivity in these investigations, though they are conducted by progressive intellectual figures; unless the elites of both 'progressives' and 'Islamists' find an objective formula to discuss the situation of the Arab region and lean to avoid ideological conflicts, Al-Rabī ${ }^{\top} \bar{u}$ does not discern any future for constructive dialogue, and as therefore for regional development (alRabī' $\left.{ }^{\mathrm{e}}, 2006: 26-57\right)$.

Al-Rabīēu quotes Mohammad al-Jābiri's alMas'ala al-Thaqāfiyya 1996 (The Cultural Issue), which is considered a revision of his and others' methodologies of reading Islamism. Al-Jābiri sets two conditions for a clear understanding: first, the scholar should be objective and keep a distance between his or her personal ideology and the examined subject; and second, the issue should be dealt with as inner, continuous and rich, not from the view point of an outsider. Consistently, he recognises (and urges other authors to do so) these movements and accepts them as constituting a de facto phenomenon that has a rational and objective basis (al-Rabī $\overline{\mathrm{u}}, 2006$ : 65-66).

Another scholar, Raḍwān al-Sayyid concedes in his book Syāsāt al-Islam al-Mu'āṣir (Politics of Contemporary Islam) that there is an 'Arab crisis' that has shaped intellectual and cultural life in general, and so the problems posed by Islamist movements should be reconsidered; he stresses the importance of contextualising the phenomenon, with all its various discourses and defects, within the whole mosaic in order to reach an effective understanding (al-Rabī $\overline{\mathrm{e}}^{\mathrm{u}}, 2006$ : 74-78).

In his Musā'alat al-Hazìma (Questioning the Defeat) Mohammad al-Anșāri agrees with both al-Sayyid and al-Jābiri, though he does not think Islamism could function as an alternative. Nonetheless, he believes that Islamist movements need to address three issues in order to succeed. First, they need to conceive a new political Islamic project that has a progressive vision. Second, they must break the connection with the suicidal violence which has stained its history, and third, they have to find a way to absorb modern civilisation and benefit from its scientific and civilising powers (al-Rabī $\overline{\mathrm{u}}, 2006$ : 84-85).

In sum, al-Rabi $\overline{1}^{\mathrm{e}} \overline{\mathrm{u}}$ warns Arab intellectuals that Islamism is not a merely temporary phenomenon which can be quickly examined and diagnosed; it is rooted in a long and rich history. He argues that the Arab masses, whose support is deemed to be the strategic power behind the Islamist movements, cannot be underestimated; they belong to Islam, and whoever claims to be a true representative of Islam will probably have the advantage of appealing to their emotions and thus secure their support.

\section{Conclusion}

The investigation above shows that although Arab critics have taken the phenomenon seriously and tried to address it in details in their works, they still need to answer two questions: the first is about the gap they have so far failed to close with their own societies and win the trust of their own people. The second is about Islam- not Muslims- as a religion that is a dominant factor among the majority of Arab societies; any work aiming to study the phenomenon needs to consider this element carefully; not only by putting it in its 
such as: how did the phenomenon of Islamism in Egypt accompany the rise of Nasirism? How can we explain the expansion of political Islam beyond Egypt to influence the youth in other Arab countries? Can we accept the psychological and sociological factors that some scholars suggest are at the root of this phenomenon? Finally, is political Islam a temporary arising from particular circumstances phenomenon?

Although al-Rabi $\overline{1}^{-} \overline{\mathrm{u}}$ ' is uncomfortable with the notion of 'Arab progressives', he seems to accept the Arab progressives' own definition: after their 1982 symposium in Switzerland they concluded that Arab progressives are 'all Arab communists, pan-Arab nationalists, Ba'thists, and Nasserists' who oppose and reject the reactionary politics and the rigidity of the Arab rightist, which are essentially Islamist (al-Rabī $\left.{ }^{\mathrm{e}} \mathrm{u}, 2006: 22\right)$.

The author thinks that this classification implies a basic problem; it is in effect a call to arms against the Islamists and is dominated by an ideology that is not prepared to engage in dialogue with the rightists but seems only to confront them. Accordingly, Arab progressives believe that the authorities must deal strictly with the rightists as an imminent danger; they urge governments to classify Islamist movements as 'extremist' and neutralise them. Al-Rabī $\bar{u}$ thinks that Arab progressives contradict the values they believe in: freedom, justice, civilised dialogue, and, on the contrary, exercise what they tend to warn people against: exclusionism and suppression.

The book's reservations on the Arab progressives' discourse include their explanations, locating, and typing of Islamism; al-Rabi $\bar{e}^{-} \bar{u}$ criticises both the psychological approach found in the works of Mohammad Arkoun and the Egyptian Ghāli Shukri, and the sociological explanations offered by the Egyptian Maḥmūd Amīn al-'Ālim and the Lebanese Husayn Marwa. The first approach proposes that the rise of Islamist movements is a result of psychological 'diseases' that caused by oppression and despair; al-Rabī ${ }^{-} \overline{\mathrm{u}}$ asks how these diseases could take hold during the glorious times of pan-Arabism and Nasirism.

In contrast, the sociological explanation tends to cite the waves of migration from villages to cities; the people who move from rural towns and villages are primitive, conservative, mostly illiterate, and naive; they believe in myths more than the power of reason; they tend to trust religious people and institutions, thus the Islamists' followers are largely composed of this class. Al-Rabīi $\bar{u}$ also disagrees with this hypothesis, arguing that this it is based on a Marxist view that contends both that farmers and villagers from a class whose culture is impoverished, and that Islam is a religion particularly suited to rural people. This discourse also contradicts itself when it says that the entire 'Arab street', including both workers and farmers, was behind the Nationalist project, but then characterises the common ideology of these people as metaphysical and religious.

The book also condemns the floundering attempts of the progressives to place Islamism in its socio-political context; there is no contemporary convincing progressive theory of religion, and this has encouraged Arab progressives to venture the field. However, instead of building their own theories, they borrow from Marxism, which they use as an unassailable model immune from all Islamist assaults. Thus, critics like Rif at al-Sayyid and Șādiq al- Aẓm declare that religion has no role to play in the political system and must not be involved in any way, and any attempt to politicise Islam is bound to fail.

$\mathrm{Al}-\mathrm{Rab}_{\overline{1}}^{\mathrm{e}} \overline{\mathrm{u}}$ rejects these ideological assumptions and argues that they inevitably lead to false judgments as well as methodologically contradictory analyses; religion in al- 'Azm's view is 'the primary ally 
Liberalism in the Post-colonial World, he states that "the problem with Yassine's ${ }^{3}$ analysis, and Islamist discourse in general, is that it reduces everything to a mere religious, ideological struggle between Islam on the one hand, and secularism and atheism, the other faces of Christianity, on the other. It is as if all the history of humanity were the history of religious struggle" (Aksikas, 2009: 106).

Aksikas thinks that although Islamists succeed to win the trust, or attention of Arab societies, this does not mean that they do realise how society functions, or should function, according to the values of modernity. Thus, he asserts, "such [Islamist]analysis emphasizes the exclusive role of religion, and denies the role of social factors in social and historical change" (Aksikas, 2009: 106).

\section{Arab Critics under Familiar Fire}

The Syrian thinker Turki al-Rabī ${ }^{e} \bar{u}$ provides in his study Al-Harkāt al-'Islāmiyya fi Manz̄ūr al-Khițāb al-'Arabi (Islamic Movements from the Perspective of Contemporary Arabic Discourse) a comprehensive but different reading of the studies devoted to an analysis of the phenomenon of Islamism. At the beginning of his review al-Rabi $\overline{\mathrm{u}}$ quotes the Moroccan historian Abdallah Laroui's Contemporary Arabic Ideology, where the latter states that modern Arab countries face three kinds of 'self-enemies' (internal threats or challenges): the liberal politician, accused of complete dependence on the West, who express his despair in severe criticism and mockery of Arab governments; The sheikh, who finds himself banned from preaching and sees nothing around him but the devil and the West controlling Muslim societies; and the young man whose hopes are too wide, and who impatiently witnesses the failure of the

\footnotetext{
${ }^{3}$ By which he means Abdessalam Yassine, the leader of Islamist Moroccan organisation al-'Adl wa al-Iḥsān (Justice and Philanthropy).
}

nation's leaders to fulfil their promises and resolve his and his generation's problems.

This disillusioned youth cannot resist the temptations of the past, which inspire him to sacrifice himself for his faith, to be re-born and live the life he wants in the hereafter. The writer $\mathrm{Sa}^{\top} \mathrm{d}$ al-Dīn Ibrāhīm calls this third type 'al-munādil al-Muslim al-sākhiț' (the struggling, discontented Muslim); he describes him as well-educated, bearded, ${ }^{4}$ but indignant. This man constitutes the distinguishing mark of the Arab world in our period; Bernard Lewis in his The Future of the Middle East warns the world that a whole generation has grown up in tragic conditions: deformed developments, undemocratic life, inefficient governments whether leftist or rightist, and huge numbers of influential preachers who enthusiastically call for the Islamisation of the Arab states without enough awareness of the modern world and its requirements (Lewis, 1997: 47).

Agreeing with Lewis's observation, al-Rabi $\overline{1}^{-} \overline{\mathrm{u}}$ adds that the continuity of both the authoritarian regimes and the perceived hostility of US polices in addition to the grievances of a young generation without hope will certainly lead to more activism and effectiveness on the part of the radical Islamist movements, even though these seem to lack a substantial political project. However, alRabi $\overline{1}^{\mathrm{u}} \overline{\mathrm{u}}$ believes that all the rash analyses of, and passionate debates about, the phenomenon make the situation worse instead of helping to reach a clear understanding (al-Rabī $\overline{\mathrm{u}}, 2006$ : 7-11).

Al-Rabī' $\bar{u}$ 's book deals with what is called literally 'the Arabic progressive discourse', addressing questions crucial in this context

\footnotetext{
${ }^{4}$ This characterisation describes a type of religious young man in the Muslim world; its mention of the beard needs a word of explanation. Beards in Islam have a symbolic importance and Muslims are encouraged to grow them.
} 
strongly influenced Quṭ as an example; his ideas were adopted extensively by later generations of Islamists. Among these ideas was his classification of the modern jāhilyya into three categories: atheism, polytheism, and Sufism.

Al-Mawdūdi believed that foreign elements such as Greek philosophy and Western sciences and arts had a destructive affect on Islamic culture and resulted in the appearance of deviant doctrines and ways of thinking within the Islamic body. Thus, he attacked the philosophical heritage, doctrines like Mu'tazila, ${ }^{2}$ and modern arts whether music, painting, and sculpture. Instead, he called on Muslims to follow the 'pure' Islamic traditions taken from the Qur'ān and the Sunna as interpreted and explained by a few scholars holding a particular doctrinal position. Abu Zayd remarks that these ideas, developed by Qutb and other Islamists, were hostile to any diversity within Islam and thus led to the advocacy of the concept of al-hākimiyya, which pits Divine law against all forms of secular reasoning. Al-hākimiyya generally means that there is no governor but Allah, whose laws must be applied and followed; therefore any secular law is clearly intended to replace the law of Allah, and must not be allowed.

Ideas advocating the enforcement of Sharī a laws and the abolition of all others, and also ideas of attacking Arab authorities and their followers gradually became popular as a result of this thinking. Abu Zayd concludes that Islamists mingle two concepts in their attack on secularism: they accuse its advocates of aiming to separate between Islam and the state, and between Islam and society. While the latter is impossible - nobody can achieve such a separation but the people themselves -

\footnotetext{
2 The Mu'tazila is a rational theological school that flourished between the eighth and tenth centuries.
}

preventing the former is the key target; controlling both religious and governing powers is the ultimate goal of political Islam (Abu Zayd, 1994).

Regarding this last point, the Algerian thinker Mohammad Arkoun comments that the Qur'ān as a text is open to a great number of interpretations, none of which can claim with certainty to be the definite truth, or to have exhausted its meanings. Thus, all schools and doctrines are called Islamic are no more than ideological movements designed to support and justify social powers competing to obtain authority and domination (Arkounm 1996: 145).

Islamist movements are the result of this problematic situation; as long as there is no one who universally agreed interpretation of the first source of Islam, it will be impossible to build a movement that completely represents Islam; any movement's claim to do so should be regarded as essentially ideological. Arkoun admits that the new global importance of Islam with its many possible dimensions has become the historically unmatched phenomenon of the age.

He rejects, however, any attempts to connect this phenomenon to efforts to revive medieval Islam; he believes that it is essentially related to the Arabs' powerful desire to regain their identity, which was being eroded by colonial ambitions in the region. Islam is felt by most Arabs to be the only aspect of their identity that can maintain their traditional social fabric endangered by cultural and economic crises; this fabric is considered essential for the future development of the nation(Arkoun, 1996: 136).

Still, the problem of political Islam is that it has no real interest in modernity, which inevitably leads to a conflict with reality, in the opinion of the originally-Moroccan and American critic Jaafar Aksikas. In his Modernities: Islamism, Nationalism, and 
of the phenomenon in the last four decades are political, socio-cultural, and economic.

The German scholar Fritz Steppat lists four reasons for the astonishing growth of political Islam. First, with the development of the new global market system these countries witnessed unbalanced population growth, and poorly planned development led to social and economic disorder and general despair. Second, Arabs were acutely of disappointed by most postcolonial governments' suppression of democracy, failure to solve societal problems, and oppression of the people.

Third, although all Arab countries gained independence, the influence of the colonial powers persisted the so-called new order, which served Western interests. Fourth, the endeavours sometimes by politicians, at other times by intellectuals, to imitate - or to enforce - the 'Western model' with its social values and orientations including liberalism, socialism, and democracy (Warburg, Jul. 2009: 663).

Baqader agrees with Frits's analysis and adds that the expansion and struggle of the Muslim Brothers and the success of the Islamic Revolution in Iran inspired Muslims and provided them with a new and private literature to deal with the challenges of the modern world. He also believes that the decline of the nationalist project after the defeat of 1967 encouraged frustrated Arabs to look for alternatives, which they found in 'Islamist' activism. Baqader finally mentions the gap that increasingly widened between elites who supported westernising initiatives and secular theories on the one hand, and the masses on the other; this eventually resulted in crisis of trust that "led the latter to reject the intellectual leadership of the former"( Baqader, 1994: 118).

Islamism under the Scalpel of Arab Critics

The phenomenon of Islamist activism has always attracted the attention of Arab intellectuals, who happen to have different standpoints. One leading study is that of the Egyptian thinker Nașr Abu Zayd, titled Naqd al-Khițāb al-Dīni (Critique of Religious Discourse); this book gave rise to great controversy and tension which reached uncontrolled levels, forcing Abu Zayd to flee to the Netherlands to save his life. The work discusses the rise of political Islam in Egypt in three chapters; it analyses the prime principles of the Islamists' discourse.

The author does not distinguish between the 'extremist' and the 'moderate' voices in that discourse; he believes the difference between the two is a matter of degree not of principles. Thus, he focuses on two key concepts of the Islamists: al-naș and al-hākimiyya (the text and the governance). The text, which consists of both the Qur'ān and the Sunna of the Prophet (his saying and actions) has remained unaltered since the early period of Islam; but the problem, in Abu Zayd's opinion, lies in the interpretation.

The human mind was encouraged to be creative in understanding the texts not only by the Qur'ān and the Sunna, but also by Islamic scholars throughout history, even those known for their strictness, who advocated the use of what is called jurisprudentially ijtihād. Islamists in modern times, however, reject this approach; they are opposed to the use of reason to interpret texts, and instead rely on the arguments of previous scholars, even though those scholars were human beings like themselves.

Abu Zayd argues that the new Islamist scholars seek to deny the mind its prime function for which Allah created it: thinking; and to imprison mankind in blind imitation. This, he states, is in clear contradiction to Islam's emphasis on rationality and can only lead to a one-dimensioned view of the religion; because Islamists deny reason; they recognise no way of understanding but theirs, and any other interpretation is condemned as a deviation. Abu Zayd uses al-Mawdūdi, who 
group movement can alone represents Islam, even though all movements - and doctrines likewise - claim they do. "Islam presents itself as the blueprint of social order, as a way of life based on rules and principles that are eternal, divinely ordained and independent of its followers. Thus it has played and continues to play an important role in the life of Muslims" (Baqader, 1994: 114).

With regard to governance, Islam does not distinguish between the state and the religious institutions; they are all under the umbrella of its law ( $\left.\operatorname{sharī}^{\prime} a\right)$, and therefore, "most political powers tried to assert their legitimacy not only by stressing that they submitted to the Islamic ideal, but also by working to protect and embody it" (Baqader, 1994: 114). Religious intellectuals (ulema) always played a major role in this process; they were greatly respected by the people as the representatives of Islam or even the leaders of the nation; and they are still considered the leaders in some discourses nowadays.

The ulema also functioned as mediators between rulers and people; on the one hand it was their mission to supervise how well Islam was being practised by the rulers, and they were on the other supposed to stress the importance of obeying the rulers and condemn - or indeed criminalise - any disobedience. However, for just this reason the ulema were brought close to the ruler's court where they were given special privileges which enhanced their power in society. It should be mentioned here that, there was always a number of ulema who refused these privileges and did not succumb to the rulers' temptations, and they were admired by the people for their wisdom, knowledge, Islamic ethics, and divine blessings (baraka).

This respect and admiration continued into the colonial period and was strengthened when the ulema confronted colonial forces and led popular rebellions against them; they became iconic heroes because of their determination to protect Islam and the nation and to fight the invaders:

The Western challenge led some thinkers - for the first time in the history of Islam - to ask questions such as, what is the secret of Western superiority? Why are we defeated? What is wrong with us? How could the community of Islam regain its leadership role and status? These questions became the basis of ongoing auto-critique in the Muslim world. This auto-critique led the ulema to play a major role in co-ordinating the struggle against the colonial powers. (Baqader, 1994: 116).

After independence, however, and contrary to their expectations, the ulema found themselves excluded from the new political systems: nationalist and socialist trends were promoted instead of the traditional Islamic ruling system, which limited the political authority of the ulema; they "were often forced to acquiesce in the loss of their legal monopoly" (Ruthven, 2007: 107), and decided to gain support among the people.

They began to create their own sphere of influence, establishing or re-establishing traditional schools based on the Islamic system, and attracting as much attention and support as possible among the masses. The seeds of some Islamist movements were planted by these means in the early decades of the twentieth century; the Muslim Brothers (founded in 1928), one of the largest and most influential Islamist parties at the present time, is a classic example.

Islamist movements have since continued to emerge in qualitatively different types in Arab and Muslim countries. Their goals and methods have varied widely; some of them have branched from - or revolted against others, while some have claimed to be unique though being clearly influenced by earlier movement. The factors behind this flourishing 
impact on the Arab masses and win their votes.

However, It has become clear with the results of the 'Arab spring' that Islamists have more to offer; in the election held after the fall of the Tunisian ex-president Zayn al- ${ }^{\circ} \bar{A}$ bidīn b. 'Ali in October 2011 the Islamist party al-Nahda swept the board, and a few months later the same thing happened in Egypt, where the Muslim Brothers' Freedom and Justice Party enjoyed an overwhelming win in the first parliamentary elections after the resignation of president Mubārak. Though the protests of 2013 ended the short but shiny spring of Muslim Brothers, Islamist movements have proved their ability to organise themselves and to win the people's trust.

This paper discusses the different opinions of Arab critics about the phenomena of Islamism and its influence on Arab societies. It attempts to highlight how realistic - or unrealistic those critics are in their endeavourer to understand the needs of their own societies. To do that the paper also surveys the foundations of Islamist movements, and the historical circumstances behind their emergence in the Arab world, in order to frame the whole picture.

\section{Historical $\quad$ Factors... $\quad$ Historical Complication}

It should be said that Islam has become the reference of the Arabs' glory; under its flags the sun of the nation shone, and every caliph considered himself, and was considered by Muslims, the carrier of that flag. Rulers throughout history have competed to prove or enhance their legitimacy and reputation by appealing to Islam. Political Islam began early in Islamic history; the conflict between 'Ali b. Abi Tâlib, the last of the 'rightly guided' caliphs and Mu'āwya b. Abi Sufyān, the founder of the Umayyad state is considered one of the first occasions on which Islam was politicised. Eventually, three main doctrines in Islam gradually developed: Sunni, Shi i, and
Sufi; many different interpretations are associated with them, and each doctrine is deemed ideal by its followers.

Beside the historical factor, the emergence of the so-called Islamic reformist movements in the eighteenth century, as a result of the anarchic state of the Ottoman Empire, is deemed a significant stage before modern Islamism. The Syrian writer Husayn al- 'Awdāt analyses the role of such movements in his book al-Nahda wa al-Hadātha Bayn al'Irtibāk wa al-'Ikhfāq (Renaissance and Modernism between Confusion and Failure).

The general weakness of the Ottoman Empire led to a social and political crisis; authoritarian misrule and corruption were widespread and growing in Arab territories, and even when desperate reform initiatives were undertaken by some late sultans under the pressure of Western powers, they served no more than to educate people about the values and concepts of the new world such as human rights. This consequently gave rise to two phenomena that would have a crucial impact on the Arab renaissance; first, the establishment of the Arab bourgeois class in which Christian Arabs played an important role, and second the appearance of Islamist religious movements in different parts of the Arab world: alWahhäbiyya (or Wahhabism, though there is no general agreement on the name) ${ }^{1}$ emerged in the Arabian Peninsula, al-Mahdiyya (Mahdism) in Sudan and al-Sanūsiyya in Libya (al- 'Awdāt, 2011: 93-42).

In his Contemporary Islamic Movements in the Arab World the scholar Abubaker Baqader elaborates on these issues; he argues first that 'the Islamic resurgence' in the modern Arab world is not a new phenomenon, but is rooted in Islamic history, and second, that no single

\footnotetext{
${ }^{1}$ Pascal Ménoret, among others, deals with this issue in a section titled Saudis Do not Call themselves 'Wahhabis' in his The Saudi Enigma: A History. (Ménoret, 2005: 52).
} 


\title{
Political Islam in Arabic Criticism: Review of Discourse
}

\author{
Dr. Adel Khamis Alzahrani \\ Associate Professor of modern criticism. \\ Arabic and Literature Dept. \\ Faculty of Arts and Humanities \\ King Abdulaziz University, \\ Email: akalzhrani@kau.edu.sa
}

\begin{abstract}
Since the 1960s, Arab critics, such as Laroui, al-Jabiri, Abu Zayd and Arkoun, have largely participated in the controversy around Islamism in the Arab world; they were, mostly, against the phenomenon, but in 2006, the Syrian Turki al-Rabi 'u's Al-Harkat al-'Islamiyya fi Manzur al-Khitab al'Arabi (Islamic Movements from the Perspective of Contemporary Arabic Discourse) provided a comprehensive, but different, reading of the studies devoted to Islamism.

The book attempts to uncover the contradictions in the works of 'Arab progressives'. Recent political events could justify this ongoing debate; Islamist movements have clearly proved their ability to organize themselves and to win the people's trust. This paper highlights the factors behind Islamism in the Arab world, and attempts to analyze the intellectual discussion around the phenomenon.

Keywords: Islamism; Arab critics; progressive discourse.
\end{abstract}

\section{Introduction}

The rise of ISIS is regarded one of the biggest and shocking stories in the last few years. Questions around its mysterious emergence and rapid spread are still meticulously unanswered; in their ISIS the State of Terror Jessica Stern \& J. Berger state that: "ISIS's short history is a series of contradictions and surprises", though they "believe that whatever its fate as an organisation, it has instituted transformative changes in strategy, messaging, and recruitment that will linger long after its so-called caliphate has crumbled to dust" (Stern \& Berger, 2015: 7). ISIS is described as 'extremist Islamist' movement, though other dimensions and factors behind its appearance are considered in the book. What is sure, one can say, is that political Islam in the Arab world is a contentious phenomenon, which has always attracted the masses' support and gained enough momentum.

History supports this assumption; the 1990s witnessed victorious elections of Islamist movements in Algeria, Jordan and Sudan. And in January 2006 Hamas, the Islamic resistance movement in the Gaza Strip, won the majority of seats in the Palestinian parliament in a free election, though this result did not win the approval of all parties. Hamas is, as its founders state, the branch of the Egyptian Muslim Brothers in Gaza, but some have claimed that its victory was due to its being a resistance movement, and have doubted the ability of Islamic movements to make an 